\title{
Regulation of Melatonin and Neurotransmission in Alzheimer's Disease
}

\author{
Jaydeep Roy ${ }^{\dagger} \mathbb{D}, \mathrm{Ka}$ Chun Tsui ${ }^{\dagger}$, Jonah Ng $^{\dagger}$, Man-Lung Fung and Lee Wei Lim *(D) \\ School of Biomedical, Sciences, Li Ka Shing Faculty of Medicine, The University of Hong Kong, \\ Hong Kong, China; jaydeep@connect.hku.hk (J.R.); tsuikc@connect.hku.hk (K.C.T.); \\ u3555462@connect.hku.hk (J.N.); fungml@hku.hk (M.-L.F.) \\ * Correspondence: drlimleewei@gmail.com \\ † Joint-first authors.
}

check for updates

Citation: Roy, J.; Tsui, K.C.; Ng, J.; Fung, M.-L.; Lim, L.W. Regulation of Melatonin and Neurotransmission in Alzheimer's Disease. Int. J. Mol. Sci. 2021, 22, 6841. https://doi.org/ $10.3390 /$ ijms 22136841

Academic Editors: Cesar Borlongan and Eleonora Napoli

Received: 26 May 2021

Accepted: 22 June 2021

Published: 25 June 2021

Publisher's Note: MDPI stays neutral with regard to jurisdictional claims in published maps and institutional affiliations.

Copyright: (C) 2021 by the authors Licensee MDPI, Basel, Switzerland. This article is an open access article distributed under the terms and conditions of the Creative Commons Attribution (CC BY) license (https:// creativecommons.org/licenses/by/ $4.0 /)$.

\begin{abstract}
Alzheimer's disease is a neurodegenerative disorder associated with age, and is characterized by pathological markers such as amyloid-beta plaques and neurofibrillary tangles. Symptoms of $\mathrm{AD}$ include cognitive impairments, anxiety and depression. It has also been shown that individuals with AD have impaired neurotransmission, which may result from the accumulation of amyloid plaques and neurofibrillary tangles. Preclinical studies showed that melatonin, a monoaminergic neurotransmitter released from the pineal gland, is able to ameliorate AD pathologies and restore cognitive impairments. Theoretically, inhibition of the pathological progression of AD by melatonin treatment should also restore the impaired neurotransmission. This review aims to explore the impact of $\mathrm{AD}$ on neurotransmission, and whether and how melatonin can enhance neurotransmission via improving AD pathology.
\end{abstract}

Keywords: melatonin; neurotransmission; Alzheimer's disease

\section{Introduction}

Alzheimer's disease (AD) is a common neurodegenerative disorder that is associated with advancing age. AD accounts for $50 \%$ to $75 \%$ of all dementia cases [1], and it is estimated there are about 50 million people with AD worldwide. With an aging global population, it is estimated the number of people with AD will increase to 152 million by 2050 [2]. AD is characterized by the development of amyloid-beta $(A \beta)$ plaques, hyperphosphorylated tau and neurofibrillary tangles (NFT) [3]. The development of these pathologies in the brains of AD patients leads to cognitive and behavioral changes, including memory loss, depression and anxiety [4]. AD affects multiple regions of the brain, including the hippocampus, subcortical nuclei, substantia nigra (SNR), ventral tegmental area (VTA) and the dorsal raphe [5]. The impact of AD in these areas may vary, including degeneration of afferent neurons, mitochondrial abnormalities and apoptosis of monoaminergic cells. The mechanism of the different effects is not currently well understood; however, it has been suggested that the lack of amyloid-beta clearance or its accumulation results in neurons becoming more susceptible to oxidative stress associated with aging, leading to impaired function [6].

Neurotransmission is the process by which a signal is conveyed between neurons via endogenous signaling molecules called neurotransmitters [7]. Neurotransmitters released from the axon terminal of one neuron cross the synaptic cleft and bind to receptors on the dendrites of another neuron, which are then converted into electrical signals. Synapse, the junction between neurons, has a tripartite structure that consists of presynaptic and postsynaptic nerve terminals along with the intimate association of glial cells [8]. Glial cells, in particular astrocytes, play an important role in regulating neurotransmission through feedback mechanism [8]. The binding of neurotransmitters onto specific postsynaptic receptors propagates signals from one neuron to another [7]. Postsynaptic receptors can be 
classified into metabotropic receptors that act through signal transduction and ionotropic receptors that act as ligand-gated channels [9]. Neurotransmitters can be classified into several types including monoaminergic and cholinergic neurotransmitters. In AD pathogenesis, important monoaminergic neurotransmitters include dopamine (DA), serotonin (5-HT) and histamine, whereas significant cholinergic neurotransmitters include gammaaminobutyric acid (GABA) and acetylcholine (ACh) $[5,10]$. In $\mathrm{AD}$, the therapeutic potential of neurotransmitter inhibitors has been well established, such as acetylcholinesterase inhibitors (AChEI) donepezil, rivastigmine, memantine and galantamine [9]. These drugs function by preventing the breakdown of ACh through inhibiting acetylcholinesterase (AChE) activity, which improves cholinergic transmission, inducing long-term potentiation in memory and learning. However, cholinesterase inhibitors only serve to alleviate the symptoms of $\mathrm{AD}$ and cannot halt the progression or reverse $\mathrm{AD}$ pathology. Interestingly, in recent years, melatonin has been proposed as an alternative neurotransmitter-based therapeutic drug.

Melatonin (N-acetyl-5-methoxytryptamine) is a monoaminergic tryptophan metabolite that is mainly synthesized in the pineal gland from its precursor serotonin. Melatonin is responsible for regulating the circadian rhythm, clearing free radicals, improving immunity and preventing oxidation of biomolecules. It has been reported that melatonin secretion gradually decreases with the progression of AD. Thus, it can be considered as a possible biomarker for $\mathrm{AD}$ [3]. Moreover, low levels of melatonin in $\mathrm{AD}$ patients have been observed to cause afternoon agitation, sleep disturbances and disrupted circadian rhythm, which further supports melatonin as a therapeutic target [11]. It has been shown that melatonin is able to inhibit the synthesis of $A \beta$ plaques, prevent the formation of fibrils and protect neurons from the toxic effects of plaque accumulation [12]. In addition, melatonin was also found be effective in improving cholinergic and glutamatergic systems $[13,14]$. This is clinically significant as melatonin not only has low toxicity, but could also be an alternative monoaminergic drug in a saturated market of cholinesterase inhibitors [3]. However, only a small number of studies have investigated the effects of melatonin on various neurotransmitters or examined its effects compared to other cholinergic drugs, thus the efficacy of melatonin as a treatment for AD is currently not well established. However, the ability of melatonin to prevent the progression of $\mathrm{AD}$ pathology together with its neuroprotective traits suggest that melatonin could be a potential treatment for AD. In this review, we examine the potential of melatonin in AD treatment and prevention. We briefly describe the hallmarks of AD and summarize the protective effects of melatonin against these hallmarks, and then highlight the findings related to melatonin's role in neurotransmission to understand the therapeutic benefits of melatonin in AD.

\section{Major Pathologies Involved in AD}

\subsection{Role of A $\beta$ Plaques and Neurofibrillary Tangles}

Our current understanding of $\mathrm{AD}$ progression in terms of the development of abnormal structures such as A $\beta$ plaques and NFT has been well documented. Amyloid-beta plaques consist of amyloid peptides of 36-43 amino acids with a molecular weight of about $4 \mathrm{kDa}$ [1]. They are generated through the cleavage of amyloid precursor protein (APP), which is a type I membrane protein encoded by the APP gene on chromosome 21. Notably, a large proportion of familial Alzheimer's patients have mutations in the APP gene. Moreover, those with Down syndrome are known to develop pathological and clinical indicators of early-onset $\mathrm{AD}$, as an extra copy of chromosome 21 leads to the production of more APP. AD is a multifactorial disease as it can arise not only from mutations in the APP gene, but also from mutations in presenilin-1 (PSEN1) and presenilin-2 (PSEN2) genes. This is significant as presenilin is involved in the processing of APP, in which it acts as the catalytic subunit of gamma-secretase that cleaves the A $\beta$ peptide from the carboxyl end of APP [15]. An alternative method of cleaving APP involves alpha-secretase, which generates soluble beta-APP (sAPP) that prevents accumulation of amyloidogenic fragments [1]. 
As our understanding of $A \beta$ plaques has increased, the amyloid cascade hypothesis was put forward for the progression of AD. This hypothesis suggests that mutations in either APP or PSEN gene lead to the accumulation of amyloid peptides, which form into beta-pleated sheet structures, a process that occurs in familial AD. Alternatively, the hypothesis also proposes that sporadic AD may occur when the normal accumulation of $A \beta$ peptides is sped up by external factors that reduce the clearance of these peptides. For instance, disrupted expression of aquaporin-4 (AQP4), which is expressed in the endfeet of astrocytes, impacts the glymphatic pathway, responsible for cleaning $A \beta$ from the brain, hence facilitate the deposit of $A \beta$ plaques [16-19]. Both pathways lead to the accumulation of $A \beta$ peptides that oligomerize to form senile plaques, resulting in a series of downstream events including synapse degeneration, inflammation, plaque deposition, tau hyperphosphorylation and neuronal death [20].

\subsection{Role of Aging}

It is well established that the risk for AD increases with aging. The structural complexity of our brains gradually decreases during the normal aging process, including reduced complexity of neuronal dendrites, synapse density and astrocyte function [20]. It has been suggested that a series of events have occurred to trigger the development of AD. The first event involves an injury that initiates the pathogenic pathway, which could explain the tightly knit relationship between AD development and age. As our body's ability to initiate a protective response in neurons begins to decline with age, any form of injury such as stroke or a traumatic brain injury may lead to the pathogenic development of $\mathrm{AD}$ [20]. The second event involves chronic inflammation that adds to the existing stress in the age-affected brain. The concept of chronic inflammation leading to AD has been well established. Studies have shown that prolonged use of non-steroidal anti-inflammatory drugs (NSAIDs) can reduce the risk of AD by 30-60\% [21]. The third event involves the altered physiology of the neurons, which can occur during the prolonged inflammatory response. It was discovered that stressed neurons can re-enter the cell cycle, which halts after DNA replication and is unable to progress into late G2/M phase or revert the cell cycle progression. As a result, these neurons have duplicate copies of DNA content resulting in dramatic cellular changes [22], which ultimately lead to AD and dementia through disrupted synaptic dysfunction, neuronal loss and deficiencies in neurotransmission.

\section{Dysfunction of Neurotransmission in AD}

As mentioned above, it is well established that neurotransmission is affected in patients with $\mathrm{AD}$, particularly the chemical neuroanatomy of monoaminergic systems including serotonergic and dopaminergic systems, cholinergic systems including acetylcholine and GABA, and glutamatergic systems [11]. Neurotransmission dysfunction mainly arises from the degeneration of neurons as a result of the toxic accumulation of $A \beta$ plaques (see Table 1 and Figure 1).

\subsection{Dysfunction of Cholinergic Neurotransmission}

One of the most well-known neurotransmitters involved in AD is acetylcholine. Acetylcholine is a neurotransmitter that is widely distributed across the brain. The neurons responsible for $\mathrm{ACh}$ production are also widely distributed, innervating the majority of the brain's neurons. Given the high distribution of ACh in the brain, it comes as no surprise that $\mathrm{ACh}$ is responsible for many physiological processes including stress response, memory and learning, which are all affected in AD [23]. The dysfunction in the neurotransmission of acetylcholine has been well documented in many studies. A study showed a negative correlation between choline acetyltransferase (ChAT), an enzyme in ACh synthesis and the degree of $\mathrm{A} \beta$ plaques in the brains of $\mathrm{AD}$ patients [24]. This finding was further supported by the discovery that the cerebral cortex had markedly reduced levels of presynaptic cholinergic markers, severe degeneration and the presence of NFT at the nucleus basalis of Meynert (NBM), which is a region responsible for ACh innervation [25]. Studies on 
TgAPP23 and 3xTg-AD mice showed a decrease ChAT level and its activity in the presence of $A \beta$ plaques in the neocortex, basal forebrain and the hippocampus [26-29]. A study on Tg2576 mice showed an association between memory loss and decreased ACh release. They discovered that 9- to 11-months-old mice had lower levels of ACh released from the hippocampus accompanied by memory deficiencies [30]. A Similar result was also found in a study on 7 months old TgCRND8 mice exhibiting increased $A \beta$ plaques, oxidative stress, inflammation and neurodegeneration [31]. In PDAPP mice, there were decreases of ChAT and AChE positive neurons [32]. In another study with the same model, reduced hippocampal ACh level found to be associated with hyper-locomotor function [33]. Interestingly, a study showed young APP/PS1 mice with cholinergic denervation had increased $\mathrm{A} \beta$ deposition accompanied by early memory impairments, suggesting a synergistic relationship between the progression of AD pathology and ACh denervation [34]. Overall, these findings indicate the decrease in ACh exacerbates or contributes to AD pathogenesis.

Another neurotransmitter involved in AD is GABA, which is the main inhibitory neurotransmitter in humans and acts to reduce the excitability of neurons throughout the nervous system. It is known to be responsible for cognition, memory, learning, motor function, circadian rhythm, neural development and adult neurogenesis [35]. Dysfunction in GABA is suspected to contribute to AD. However, the findings on the effects of GABA levels in AD vary from study to study. A study on both APP/PS1 and 5xFAD mice found that astrocytes could produce a large amount of GABA in the dentate gyrus of the hippocampus, whereas suppressing GABA production restored learning and memory [36]. In $A \beta P P s w e-P S 1 d E 9$ and TgCRND8 mice, accumulation of $A \beta$ plaques and lower amounts of GABA were found in the striatum, hippocampus and cortex $[37,38]$. Nevertheless, an analysis of GABA levels in the human AD brain showed a general trend of either decreased or no change of GABA level in the brain regions such as hippocampus, subiculum, thalamus, subthalamic nucleus, cingulate cortex, amygdala and putamen [35]. A main concern of these studies is that they quantified GABA from post-mortem tissues. Post-mortem studies usually measure GABA by examining the activity of its synthesizing enzyme glutamic acid decarboxylase (GAD), but GAD is easily affected by pre-mortem environments, which can affect the measurements [39]. As such, more research is needed to understand the contribution of GABA levels and transmission in AD.

The glutamatergic system is tightly linked to GABA, given that glutamate is the precursor of GABA, which is converted into GABA by GAD [9]. However, in contrast with GABA, glutamate is an excitatory neurotransmitter. Glutamate is known to control cognition, memory and learning [40]. In $\mathrm{AD}$, it has been shown there is a constant abnormal activation of a glutamatergic receptor, namely $N$-methyl-D-aspartate (NMDA) receptor [41,42]. NMDA receptors can be found within the extra-synaptic and synaptic regions. Overstimulation of the extra-synaptic NMDA receptor, for instance the GluN2Bcomposed NMDA receptors [43], leads to the loss of mitochondrial membrane potential, prolonged activation of extra-synaptic NMDA receptors, influx of $\mathrm{Ca}^{2+}$ ions, efflux of $\mathrm{Mg}^{2+}$ ions and excitotoxicity-induced neuronal loss [44]. This is in contrast to synaptic NMDA receptors, which are known to promote cell survival and synaptic activity [45]. In general, glutamate is released from the presynaptic terminals following an event of neuronal depolarization, and it activates different metabotropic and ionotropic receptors of postsynaptic, presynaptic neurons or even glial cells. Glutamate is then removed from the extracellular space by either excitatory amino acid transporters $1 / 2$ (EAAT1/2) that located on the astrocytes or EAAT2/5 on the presynaptic terminal [46], which allows glutamate to be reused and secreted from the presynaptic neuron. EAATs are the primary mediators of excitatory transmission and glutamate transport in the CNS. Excitotoxicity occurs when glutamate release exceeds the reuptake of glutamate by EAATs, or when there is a decrease in EAAT expression, [47]. Studies have shown that in individuals with $A D, A \beta$ increases glutamate availability by restricting the glutamate recycling mechanisms [48], thereby inducing glutamate release from astrocytes [49] and directly regulating the electrophysiological function of NMDA receptors [47]. It has been suggested that activation of the NMDA 
receptor increases $A \beta$ production by inducing a shift from $\alpha$-secretase to $\beta$-secretase, which alludes to overproduction of $A \beta$ even in the condition of mild dysregulation of glutamatergic neurotransmission [47], and this leads to a vicious cycle of constant overstimulation of extra-synaptic NMDA receptors. This further triggers the signals for cell death and overwhelms the aforementioned synaptic NMDA receptor-mediated signals for cell survival [44]. Next, the balance is worsened by $A \beta$, in which damage of the glutamatergic neurotransmission, regulates the number of synaptic NMDA receptors through decreased expression and endocytosis of synaptic NMDA receptors, as well as limiting the synaptic plasticity [50]. Subsequently, the balance between synaptic and extra-synaptic NMDA receptors is disrupted, and this contributes to dysfunction of the glutamatergic system and its downstream signaling pathways that eventually leads to synaptic damage and neuronal death [44]. A study on A $\beta$ PP/PS mice found significantly increased potassium-evoked glutamate release occurred in CA1 of the hippocampus prior to cognitive decline [51], suggesting that glutamate levels can act as an early biomarker for AD. However, this was contradicted in a study using A $\beta$ PPswe-PS1dE9 mice, which found a significant decrease in cortical glutamate accompanied with a decrease in glucose, GABA and glutamate in the hippocampus and striatum when compared with wild-type mice [37]. Another study on PS2APP mice also found a significant reduction of glutamate in frontal cortex [52]. Abnormal function of glutamate receptor GluN2B and loss of metabotropic glutamate receptor 2 were also found in the same model $[53,54]$. Interestingly, an increase in the level of glutamate receptor GluN1 was observed in the neocortex, hippocampus and cerebellum, while increase of GluA2, was found only in the neocortex of TgCRND8 mice [55]. Importantly, mitochondrial damage-mediated excessive $\mathrm{Ca}^{2+}$ influx in glutamatergic neurons also led to cholinergic system dysfunction by lowering choline acetyltransferase and ACh level. These results suggest that glutamatergic activity and its neurotransmitter cycle is impaired in AD. Given that the contrasting results could be due to variations in the study designs, more research is needed to improve our understanding of the glutamatergic system in $\mathrm{AD}$.

\subsection{Dysfunction of Monoaminergic Neurotransmission}

The involvement of monoaminergic systems in AD has been well documented. Functional and structural changes of monoaminergic systems have been clearly shown to be involved in $\mathrm{AD}$ pathophysiology. In particular, the serotonergic system has been implicated in $\mathrm{AD}$ progression. Serotonin, also known as 5-hydroxytryptamine (5-HT), is a neurotransmitter produced from L-tryptophan by tryptophan hydroxylase. It regulates memory, learning, cognition, mood, sleep and other physiological processes [11]. Individuals with AD due to damaged serotonergic system have reduced 5-HT levels, resulting in altered mood, emotional expression and recognition; disrupted appetite and sleep-wake cycle; and confusion, agitation and depression [56]. A study on APPswe/PS1dE9 mice with A $\beta$ plaque accumulation showed they exhibited prominent monoaminergic neurodegeneration in forebrain 5-HT axons accompanied by anxiety-related behaviors at 18 months [57]. An animal study on Swiss mice also showed a disrupted serotonergic system, in which $A \beta$ plaques were found to disturb the homeostatic regulation of 5-HT resulting in depressivelike behavior [58]. Another study on APPswe/PS1dE9 mice showed a significant decrease in 5-HT2A receptor binding, which lowered serotonergic system activity [59]. In addition to reduced 5-HT secretions, it was shown that serotonergic denervation of the neocortex and hippocampus was accompanied by decreased production of 5-HIAA, a metabolite of 5-HT. Decreases in both 5-HT and 5-HIAA were found to be correlated with an increase in NFT, suggesting serotonergic systems were impaired in parallel with AD progression [60]. Furthermore, an interesting relationship between $\mathrm{AD}$ and the serotonergic system was found in the control of sleep-wake by the serotonergic DRN. In a study on APPswe/PS1dE9 mice, plaque formation led to sleep-wake cycle deterioration [61]. However, it was also shown that lack of sleep caused poor clearance of $A \beta$ plaques, resulting in more plaque formation that then exacerbates the sleep deprivation, forming a vicious cycle. Thus, the 
decrease in serotonergic activity in $\mathrm{AD}$, in turn, leads to further disease progression, which illustrates the importance of the serotonergic system on AD development.

Another important monoaminergic system affected in $\mathrm{AD}$ is the dopaminergic system. Dopamine (DA) is responsible for the control of mood and multiple cognitive functions such as attention, working memory, thinking, social behaviors and learning [11]. It is synthesized from tyrosine by tyrosine hydroxylase [9] by dopaminergic neurons located in the mesencephalon and diencephalon, such as the substantia nigra pars compacta (SNc) and the VTA [62]. Dysfunction in the dopaminergic system in AD has been well documented in many studies. Reduction in DA, its metabolites and receptors have been observed in patients with AD [63]. In TgCRND8 AD mice, a decrease in the level of dopamine was found in the hippocampus, whereas, the increases of dopamine were observed in the frontal cortices and neostriata, suggesting dopaminergic dysfunction in AD [64]. A study on 5xFAD mice showed there was a significant decrease in both TH+ and TH- cells in DAproducing regions, and SNR-VTA networks were altered to enhance the synchronization of neuronal firing activity in DA-producing nuclei [65]. In addition, an animal study on a Tg2576 mouse model of AD found significant degeneration in VTA dopaminergic neurons compared to wild-type mice [66]. These results support the notion that neurological and cognitive deficits in AD are associated with disruptions in the dopaminergic system.

Table 1. In vivo studies related to neurotransmission in AD. Abbreviations: 5 HT, 5-hydroxy-tryptamine, Serotonin; ACh, Acetylcholine; AChE, Acetylcholinesterase; APPswe, Amyloid-beta precursor protein with Swedish mutation; A $\beta$, Amyloid-beta; A $\beta \mathrm{O}$, Amyloid-beta oligomers; A $\beta \mathrm{PP}$, Amyloid-beta precursor protein; ChAT, Choline acetyltransferase; DA, Dopamine; DAergic, Dopaminergic; GABA, Gamma-aminobutyric acid; MAergic, Monoaminergic; mGlu2, Metabotropic glutamate receptor 2; NA, Noradrenergic; NMDAR, N-methyl-D-aspartate receptor; PS, presenilin transgenic; SN, Substantia nigra; $\mathrm{TH}-$, Tyrosine hydroxylase negative; $\mathrm{TH}+$, Tyrosine hydroxylase positive; VTA, Ventral tegmental area.

\begin{tabular}{|c|c|c|c|c|c|c|}
\hline Animal Model. & Gender & Age & Pathology Involved & $\begin{array}{l}\text { Neurotransmission } \\
\text { Dysfunction }\end{array}$ & $\begin{array}{c}\text { Behavioral } \\
\text { Effects }\end{array}$ & References \\
\hline $\begin{array}{l}\text { APPswe/PS1dE9 } \\
\text { mice }\end{array}$ & $\mathrm{N} / \mathrm{A}$ & $\begin{array}{l}4-18 \text { months } \\
\text { old }\end{array}$ & $\begin{array}{l}\text { Degeneration and loss of } \\
\text { forebrain 5-HT and NA } \\
\text { axons after A } \beta \text { deposits }\end{array}$ & $\begin{array}{l}\text { Monoaminergic } \\
\text { neurodegeneration }\end{array}$ & $\begin{array}{l}\text { Anxiety-related } \\
\text { behaviors in } \\
18 \text { months }\end{array}$ & [57] \\
\hline $\begin{array}{l}\text { Swiss mice } \\
\text { treated with } \mathrm{A} \beta \mathrm{O}\end{array}$ & $\mathrm{N} / \mathrm{A}$ & 3 months old & $\begin{array}{l}\text { Development of } \mathrm{A} \beta \\
\text { plaques }\end{array}$ & $\begin{array}{l}\mathrm{A} \beta \mathrm{O} \text { disrupts } 5-\mathrm{HT} \\
\text { homeostasis }\end{array}$ & $\begin{array}{l}\text { Depressive-like } \\
\text { behavior }\end{array}$ & [58] \\
\hline $\begin{array}{l}\text { APPswe/PS1dE9 } \\
\text { mice }\end{array}$ & Male & $\begin{array}{l}4,8, \\
11 \text { months } \\
\text { old }\end{array}$ & $\begin{array}{l}\text { Progressive accumulation } \\
\text { of } A \beta \text { protein. }\end{array}$ & $\begin{array}{l}\text { Significant decrease in } \\
\text { 5-HT2A receptor binding }\end{array}$ & $\begin{array}{l}\text { Memory } \\
\text { impairment }\end{array}$ & [59] \\
\hline 5xFAD mice & Male & 6 months old & $\begin{array}{l}\text { Significant decrease of } \\
\text { both TH+ and TH- cells in } \\
\text { DA-producing areas }\end{array}$ & $\begin{array}{l}\text { SN-VTA networks are } \\
\text { enhanced to the } \\
\text { synchronization of } \\
\text { neuronal firing activity in } \\
\text { DA-producing nuclei }\end{array}$ & $\begin{array}{l}\text { Cognitive } \\
\text { malfunc- } \\
\text { tion } \\
\text { Synaptic } \\
\text { malfunc- } \\
\text { tion }\end{array}$ & [65] \\
\hline Tg2576 mice & Male & $\begin{array}{l}2 \text { and } \\
6 \text { months old }\end{array}$ & $\begin{array}{l}\text { Degeneration of VTA } \\
\text { DAergic neurons }\end{array}$ & $\begin{array}{l}\text { Reduced noradrenergic } \\
\text { transmission in dorsal } \\
\text { subiculum }\end{array}$ & $\begin{array}{l}\text { Age-related } \\
\text { impairment of } \\
\text { memory and } \\
\text { non-cognitive } \\
\text { functions }\end{array}$ & [66] \\
\hline Tg2576 mice & $\mathrm{N} / \mathrm{A}$ & $\begin{array}{l}4-6 \text { and } \\
9-11 \text { months } \\
\text { old }\end{array}$ & $\begin{array}{l}\mathrm{A} \beta \text { were prominent in } \\
20 \text {-month-old mice }\end{array}$ & $\begin{array}{l}\text { Reduced ACh release } \\
\text { from hippocampus in 9- } \\
\text { to 11-month-old mice }\end{array}$ & $\begin{array}{c}\text { Memory } \\
\text { impairment } \\
\text { present in 9- to } \\
\text { 11-month-old } \\
\text { mice }\end{array}$ & [30] \\
\hline APP/PS1 mice & $\mathrm{N} / \mathrm{A}$ & $\begin{array}{l}3 \text { and } \\
7 \text { months old }\end{array}$ & $\begin{array}{c}\mathrm{A} \beta \text { plaques deposition } \\
\text { after cholinergic } \\
\text { degeneration }\end{array}$ & $\begin{array}{ll}\text { - } & \text { Dramatically } \\
\text { reduced cholinergic } \\
\text { neurons } \\
\text { - } \quad \text { Neuronal loss in } \\
\text { nucleus basalis }\end{array}$ & $\begin{array}{ll}\text { - } & \text { Early } \\
\text { memory } \\
\text { impairment } \\
\text { - } \\
\text { Progressive } \\
\text { impairment }\end{array}$ & {$[34]$} \\
\hline
\end{tabular}


Table 1. Cont.

\begin{tabular}{|c|c|c|c|c|c|c|}
\hline Animal Model. & Gender & Age & Pathology Involved & $\begin{array}{c}\text { Neurotransmission } \\
\text { Dysfunction }\end{array}$ & $\begin{array}{l}\text { Behavioral } \\
\text { Effects }\end{array}$ & References \\
\hline $\begin{array}{l}\text { APP / PS1 and } \\
5 x F A D \text { mice }\end{array}$ & $\mathrm{N} / \mathrm{A}$ & $\begin{array}{l}8 \text { and } \\
13 \text { months } \\
\text { old }\end{array}$ & $\begin{array}{l}\mathrm{A} \beta \text { plaques deposition } \\
\text { and reactive astrocytes }\end{array}$ & $\begin{array}{l}\text { Aberrant increase in } \\
\text { GABA release from } \\
\text { reactive astrocytes }\end{array}$ & $\begin{array}{l}\text { Impaired learning } \\
\text { and memory }\end{array}$ & [36] \\
\hline $\mathrm{A} \beta \mathrm{PP} / \mathrm{PS}$ mice & Male & $\begin{array}{l}2-4 \text { months } \\
\text { old }\end{array}$ & $\begin{array}{l}\text { Abnormal glutamate } \\
\text { release precedes cognitive } \\
\text { decline }\end{array}$ & $\begin{array}{l}\text { Significantly increased } \\
\text { potassium-evoked } \\
\text { glutamate release in CA1 }\end{array}$ & Cognitive decline & {$[51]$} \\
\hline $\begin{array}{l}\text { AßPPswe- } \\
\text { PS1dE9 } \\
\text { mice }\end{array}$ & $\mathrm{N} / \mathrm{A}$ & 6 months old & Deposition of $A \beta$ plaques & $\begin{array}{l}\text { - Significant decrease } \\
\text { in cortical glutamate } \\
\text { and GABA } \\
\text { Glucose, GABA and } \\
\text { glutamate reduced } \\
\text { in hippocampus and } \\
\text { striatum }\end{array}$ & $\begin{array}{l}\text { Impairment of } \\
\text { cognitive function } \\
\text { and memory }\end{array}$ & [37] \\
\hline TgAPP23 mice & $\begin{array}{l}\text { Male and } \\
\text { female }\end{array}$ & $\begin{array}{l}24 \text { months } \\
\text { old }\end{array}$ & $\begin{array}{c}\text { Deposition of } A \beta \text { plaques } \\
\text { and cholinergic } \\
\text { degeneration }\end{array}$ & $\begin{array}{ll}\text { - } & \text { Decreased } \\
\text { ChAT-positive } \\
\text { boutons in } \\
\text { neocortex } \\
\text { Significant } \\
\text { reduction of } \\
\text { ChAT-positive } \\
\text { neurons volume in } \\
\text { basal forebrain }\end{array}$ & $\mathrm{N} / \mathrm{A}$ & [26] \\
\hline PS2APP mice & Female & $\begin{array}{l}20 \text { or } \\
24 \text { months } \\
\text { old }\end{array}$ & Deposition of $A \beta$ plaques & $\begin{array}{l}\text { Significant reduction of } \\
\text { glutamate level in frontal } \\
\text { cortex }\end{array}$ & $\mathrm{N} / \mathrm{A}$ & {$[52]$} \\
\hline TgAPP23 mice & $\mathrm{N} / \mathrm{A}$ & $\begin{array}{l}\text { 7-8 months } \\
\text { old }\end{array}$ & $\begin{array}{l}\text { Dysfunction of cholinergic } \\
\text { and monoaminergic } \\
\text { systems }\end{array}$ & $\begin{array}{l}\text { Decreased AChE } \\
\text { and ChAT activity } \\
\text { in basal forebrain } \\
\text { nuclei } \\
\text { Increased 5-HT } \\
\text { levels in parietal } \\
\text { cortex and occipital } \\
\text { cortex }\end{array}$ & $\mathrm{N} / \mathrm{A}$ & [27] \\
\hline PDAPP mice & $\begin{array}{l}\text { Male and } \\
\text { female }\end{array}$ & $\begin{array}{l}4-6 \text { months } \\
\text { old }\end{array}$ & Deposition of $\mathrm{A} \beta$ plaques & $\begin{array}{l}\text { Reduced basal and } \\
\text { evoked ACh release from } \\
\text { hippocampus }\end{array}$ & $\begin{array}{l}\text { Hyper-locomotor } \\
\text { function }\end{array}$ & [33] \\
\hline 3xTg-AD mice & $\begin{array}{l}\text { Male and } \\
\text { female }\end{array}$ & $\begin{array}{c}2-4,13-15 \\
\text { and } \\
\text { 18-20 months } \\
\text { old }\end{array}$ & $\begin{array}{c}\text { A } \beta \text { plaques deposition } \\
\text { with cholinergic } \\
\text { degeneration and } \\
\text { alteration of neurotrophic } \\
\text { factors }\end{array}$ & $\begin{array}{l}\text { Reduced ChAT in } \\
\text { medial } \\
\text { septum/vertical } \\
\text { limb of the diagonal } \\
\text { band of Broca in 18- } \\
\text { to 20-month-old } \\
\text { mice } \\
\text { Decreased } \\
\text { hippocampal ChAT } \\
\text { activity in 13- to } \\
\text { 15-month-old mice }\end{array}$ & $\mathrm{N} / \mathrm{A}$ & [28] \\
\hline hAPP-J20 mice & $\mathrm{N} / \mathrm{A}$ & 6 months old & $\begin{array}{l}\text { Altered synaptic plasticity } \\
\text { and cognitive function }\end{array}$ & $\begin{array}{l}\text { Significantly decreased } \\
\text { phospho GluN2B levels } \\
\text { and hippocampal LTP }\end{array}$ & $\begin{array}{l}\text { Impaired learning } \\
\text { and memory }\end{array}$ & [42] \\
\hline TgCRND8 mice & $\mathrm{N} / \mathrm{A}$ & $\begin{array}{l}2 \text { and } \\
7 \text { months old }\end{array}$ & $\begin{array}{c}\text { A } \beta \text { plaques deposition, } \\
\text { oxidative stress, reactive } \\
\text { glial cells and } \\
\text { neurodegeneration }\end{array}$ & $\begin{array}{l}\text { Reduced ChAT-positive } \\
\text { neurons and ACh levels. }\end{array}$ & $\begin{array}{l}\text { Cognitive } \\
\text { impairment }\end{array}$ & [31] \\
\hline PS2APP mice & Male & $\begin{array}{l}5,9,13 \text { and } \\
17 \text { months } \\
\text { old }\end{array}$ & Deposition of $A \beta$ plaques & $\begin{array}{l}\text { Significant loss of mGlu2 } \\
\text { receptors in entorhinal } \\
\text { cortex and lacunosum } \\
\text { moleculare regions }\end{array}$ & $\mathrm{N} / \mathrm{A}$ & [53] \\
\hline
\end{tabular}


Table 1. Cont.

\begin{tabular}{|c|c|c|c|c|c|c|}
\hline Animal Model. & Gender & Age & Pathology Involved & $\begin{array}{c}\text { Neurotransmission } \\
\text { Dysfunction }\end{array}$ & $\begin{array}{c}\text { Behavioral } \\
\text { Effects }\end{array}$ & References \\
\hline PS2APP mice & Male & $\begin{array}{l}\text { 3-4 months } \\
\text { old }\end{array}$ & Altered synaptic plasticity & $\begin{array}{l}\text { Aberrant } \\
\text { GluN2B-NMDAR } \\
\text { function }\end{array}$ & $\mathrm{N} / \mathrm{A}$ & [54] \\
\hline PDAPP mice & Male & $\begin{array}{l}2,4,12 \text { and } \\
24 \text { months } \\
\text { old }\end{array}$ & $\begin{array}{c}\mathrm{A} \beta \text { plaques deposition } \\
\text { with cholinergic } \\
\text { degeneration }\end{array}$ & $\begin{array}{ll}\text { - } & \text { Reduced } \\
\text { Cholinergic nerve } \\
\text { terminals density } \\
\text { Significantly } \\
\text { decreased ChAT } \\
\text { activity }\end{array}$ & $\mathrm{N} / \mathrm{A}$ & [32] \\
\hline 3xTg-AD mice & $\mathrm{N} / \mathrm{A}$ & $\begin{array}{l}\text { 9-23 months } \\
\text { old }\end{array}$ & Deposition of $A \beta$ plaques & $\begin{array}{l}\text { Reduced ChAT and } \\
\text { AChE-positive neurons }\end{array}$ & $\mathrm{N} / \mathrm{A}$ & [29] \\
\hline TgCRND8 mice & Male & 3 months old & $\begin{array}{l}\text { Deposition of } \mathrm{A} \beta \text { plaques } \\
\text { and neuronal } \\
\text { degeneration }\end{array}$ & $\begin{array}{l}\text { - Significantly } \\
\text { increased GluN1 in } \\
\text { neocortex, } \\
\text { hippocampus and } \\
\text { cerebellum. } \\
\text { Significantly } \\
\text { increased GluA2 in } \\
\text { neocortex but } \\
\text { decreased in } \\
\text { hippocampus }\end{array}$ & $\begin{array}{l}\text { Cognitive } \\
\text { impairment }\end{array}$ & [55] \\
\hline TgCRND8 mice & $\begin{array}{l}\text { Male and } \\
\text { female }\end{array}$ & $\begin{array}{l}2-3 \text { and } \\
12-13 \text { months } \\
\text { old }\end{array}$ & Deposition of $A \beta$ plaques & $\begin{array}{l}\text { Decreased } \\
\text { glutamate in } \\
\text { hippocampus, } \\
\text { cortex, frontal cortex } \\
\text { and midbrain } \\
\text { Decreased GABA in } \\
\text { hippocampus, } \\
\text { cortex and midbrain }\end{array}$ & $\mathrm{N} / \mathrm{A}$ & [38] \\
\hline TgCRND8 mice & Male & 3 months old & $\begin{array}{c}\text { Dysfunction of } \\
\text { dopaminergic system }\end{array}$ & $\begin{array}{l}\text { - Increased dopamine } \\
\text { level in the } \\
\text { neostriata and } \\
\text { frontal cortices } \\
\text { Decreased } \\
\text { dopamine level in } \\
\text { the hippocampus }\end{array}$ & $\begin{array}{l}\text { Cognitive } \\
\text { impairment }\end{array}$ & [64] \\
\hline
\end{tabular}






Figure 1. Dysfunction of neurotransmission in AD. Accumulation of A $\beta$ plaques and NFT in AD cause impairment of the circadian rhythm, cognition, learning, memory, motor function, mood, sleep and stress response. These pathologies are toxic to neurotransmission systems, affecting cholinergic, glutamatergic, serotonergic and dopaminergic systems. Amyloid-beta plaques and NFT can inhibit the release of ACh and choline acetyltransferase, an enzyme that regulates ACh synthesis, which reinforces the inhibition effect of ACh. Amyloid-beta plaques and NFT can cause mitochondrial damage in glutamatergic neurons. The mitochondrial damage leads to inflammation due to excessive influx of $\mathrm{Ca}^{2+}$ and excessive efflux of $\mathrm{Mg}^{2+}$ that affect the activation of glutamatergic neurons and decreases the activation of NMDA receptor. The excessive influx of $\mathrm{Ca}^{2+}$ in glutamatergic neurons leads to inhibition of choline acetyltransferase and further inhibits the synthesis of ACh. However, the detailed mechanisms are not yet understood, as some studies showed the upregulation of GABA in certain regions but downregulation of GABA in other regions. Amyloid-beta plaques also disrupt the homeostatsis of serotonin (5-HT) by inhibiting the binding of serotonin receptor (5-HT2A) and disrupting the dopaminergic system. Abbreviations: A $\beta$, Amyloid-beta; NFT, neurofibrillary tangle.

\section{Role of Melatonin against AD Hallmarks}

As serotonin is the precursor of melatonin, it stands to reason that melatonin would be closely associated to the pathogenesis of AD. Evidence from various preclinical studies support that melatonin has therapeutic effects against AD (see Tables 2 and 3). Melatonin has been shown to ameliorate the effects of AD in multiple ways, primarily in the processing of $\mathrm{A} \beta$ plaques and in reducing tau hyperphosphorylation $[3,67]$.

\subsection{Anti-Amyloidogenic Effects}

Melatonin was found to be able to disrupt the histamine-aspartate salt bridges in A $\beta$ peptides, resulting in destabilization of the beta-sheet structures and leading to a large difference in beta-sheet content between $\mathrm{A} \beta$ plaques incubated with and without melatonin [68]. Similar to other anti-amyloidogenic substances, melatonin is able to inhibit aggregation of $\mathrm{A} \beta$ plaques to a certain degree, as revealed through electrospray ionization mass spectrometry (ESI-MS) [69]. Many studies support melatonin's ability to reduce A $\beta$ 
plaque levels in the brain. For instance, a study on A $\beta$ PP/PS mice found that melatonin was able to reduce the amount of amyloid plaques in the hippocampus and frontal cortex, which was accompanied by improved spatial learning and memory [70,71]. Additionally, it was reported that melatonin was able to inhibit the expected time-dependent development of $\mathrm{A} \beta$ plaques in Tg2576 mice [72]. Another study showed that melatonin was unable to clear plaques or prevent further $A \beta$ plaque generation in older Tg2576 mice [73]. Interestingly, melatonin was also found the ability to increase the removal of $A \beta$ by facilitating the glymphatic system [74,75]. A clinical study has shown that the elimination of $A \beta$ in sleeping brain is drastically increased compared to waking brain [74]. It was further proved in a study on $\operatorname{Tg} 2576$ mouse model, where melatonin treatment was able to augment the clearance of $A \beta$ [75]. These findings suggest that melatonin can successfully prevent $A \beta$ pathology and modulate APP metabolism, but is unable to exert anti-amyloidogenic effects once there is severe $A \beta$ plaque deposition. This supports that melatonin may be more effective as a preventive drug rather than for treating the effects of AD. However, the mechanisms underlying the ability of melatonin to reduce $A \beta$ plaque levels are not clear.

\subsection{Inhibition of Tau Hyperphosphorylation}

The ability of melatonin to inhibit tau hyperphosphorylation has been well documented in multiple in vitro and in vivo studies. For example, studies on N2a neuroblastoma cells with hyperphosphorylated tau induced by either calyculin-A [76] or wortmannin [77] showed that melatonin could maintain cell viability by inhibiting tau hyperphosphorylation. In a study on 3xTg-AD mice, melatonin was shown to decrease the level of hyperphosphorylated tau, and together with exercise was also able to decrease the level of $A \beta$ oligomers [78]. In the same study, melatonin was able to protect against cognitive impairments, brain oxidative stress and decreased mitochondrial DNA. In addition, a study on ICR mice injected with $A \beta$ plaques to induce $A D$ showed they had decreased expression of hyperphosphorylated tau that resulted in improved neuron viability [79]. Furthermore, the inhibition of the melatonin synthesizing enzyme 5-hydroxyindole-O-methyltransferase was found to cause tau phosphorylation and spatial memory impairments, which were reversed by injection of melatonin supplementation for 1 week [80]. These findings indicate that melatonin can ameliorate the symptoms of AD through arresting tau hyperphosphorylation.

Table 2. In vitro studies related to the neuroprotective effects of melatonin in AD. Abbreviations: C6, Rat glial cell; HeLa, Immortal human cell line; N1E-115, Mouse neuroblastoma cell line; PC12, Rat pheochromocytoma cell line; sAPP, Soluble derivates of Amyloid-beta precursor protein; SHSY5Y, Human neuroblastoma cell line; SK-N-SH, Human neuroblastoma cell line; SV770, Monkey kidney cell line; U-138, Human astrocytic cell line.

\begin{tabular}{ccc}
\hline Study Model & Effects on AD Pathology & References \\
\hline $\begin{array}{c}\text { Multiple cell types (SK-N-SH, } \\
\text { SHSY5, U-138, SV770, C6, } \\
\text { PC12, N1E-115) }\end{array}$ & $\begin{array}{c}\text { Decrease in soluble APP } \\
\text { secretion in PC12, SV770, } \\
\text { U-138, HeLa, N1E-115 }\end{array}$ & [1] \\
N2a neuroblastoma cell & $\begin{array}{c}\text { Protective effects against tau } \\
\text { hyperphosphorylation } \\
\text { induced by wortmannin }\end{array}$ & {$[77]$} \\
N2a neuroblastoma cell & $\begin{array}{c}\text { Protective effects against tau } \\
\text { hyperphosphorylation } \\
\text { induced by calyculin-A }\end{array}$ & {$[76]$} \\
\hline
\end{tabular}


Table 3. In vivo studies related to the neuroprotective effects of melatonin in AD. Abbreviations: AChE, Acetylcholinesterase; APP, Amyloid-beta precursor protein; A $\beta$, Amyloid-beta, A $\beta O$, Amyloid-beta oligomers; BDNF, Brain-derived neurotrophic factor; ChAT, Choline acetyltransferase; CREB, cAMP Response Element-Binding Protein; LPS, Lipopolysaccharides; SD, Sprague Dawley.

\begin{tabular}{|c|c|c|c|c|c|c|c|}
\hline $\begin{array}{c}\text { Animal } \\
\text { Model }\end{array}$ & Gender & Age & $\begin{array}{l}\text { Treatment } \\
\text { Dosage and } \\
\text { Duration }\end{array}$ & $\begin{array}{l}\text { AD Pathology } \\
\text { Involved }\end{array}$ & Effects on AD Pathology & $\begin{array}{l}\text { Effects on } \\
\text { Neurotrans- } \\
\text { mission }\end{array}$ & References \\
\hline Tg2576 mice & $\mathrm{N} / \mathrm{A}$ & $\begin{array}{l}8,9.5,11 \\
12.5 \text { months } \\
\quad \text { old }\end{array}$ & $\begin{array}{c}0.5 \mathrm{mg} / \mathrm{mL}, 4 \\
5.5,7 \\
8.5 \text { months }\end{array}$ & $\begin{array}{l}\text { Plaque-like } \\
\text { deposits of } \\
\text { amyloid-beta }\end{array}$ & $\begin{array}{l}\text { - } \\
\text { A } \beta \text { levels, abnormal } \\
\text { nitration on proteins } \\
\text { - } \quad \text { Increased mice survival }\end{array}$ & $\mathrm{N} / \mathrm{A}$ & [72] \\
\hline $\begin{array}{l}\text { ICR mice } \\
\text { treated with } \\
\quad A \beta_{1-42}\end{array}$ & Male & $\mathrm{N} / \mathrm{A}$ & $\begin{array}{c}10 \mathrm{mg} / \mathrm{kg}, 5 \\
\mathrm{mg} / \mathrm{kg}, 2.5 \\
\mathrm{mg} / \mathrm{kg}, 14 \\
\text { days }\end{array}$ & $\begin{array}{l}\text { Affected } \\
\text { cognitive } \\
\text { functions }\end{array}$ & $\begin{array}{l}\text { Improved cognitive } \\
\text { deficits and spontaneous } \\
\text { activity of mice } \\
\text { Reduced } \\
\text { hyperphosphorylated tau } \\
\text { expression }\end{array}$ & $\begin{array}{l}\text { Improved } \\
\text { neuron } \\
\text { viability }\end{array}$ & [79] \\
\hline $\begin{array}{l}\mathrm{A} \beta \mathrm{PP} / \mathrm{PS} \\
\text { mice }\end{array}$ & $\mathrm{N} / \mathrm{A}$ & $\begin{array}{l}4 \text { months } \\
\text { old }\end{array}$ & $\begin{array}{c}100 \mu \mathrm{g} / \mathrm{mL}, 0.5 \\
\mathrm{mg} / \text { day }\end{array}$ & $\begin{array}{l}\text { Amyloid } \\
\text { plaques, } \\
\text { behavioral } \\
\text { deficits }\end{array}$ & $\begin{array}{l}\text { - } \\
\text { spelatonin improved } \\
\text { memory learning and } \\
\text { A } \beta \text { load in hippocampus } \\
\text { and frontal cortex were } \\
\text { reduced }\end{array}$ & $\mathrm{N} / \mathrm{A}$ & [44] \\
\hline $\begin{array}{l}\mathrm{APP} / \mathrm{PS} 1 \\
\text { mice }\end{array}$ & $\mathrm{N} / \mathrm{A}$ & $\begin{array}{l}2- \\
2.5 \text { months } \\
\text { old }\end{array}$ & $100 \mathrm{mg} / \mathrm{L}$ & $\mathrm{A} \beta$ plaques & $\begin{array}{l}\text { Reduced } \mathrm{A} \beta \text { plaques } \\
\text { deposition in } \\
\text { hippocampus and } \\
\text { entorhinal cortex } \\
\text { Decreased inflammatory } \\
\text { cytokines in hippocampus }\end{array}$ & $\mathrm{N} / \mathrm{A}$ & {$[71]$} \\
\hline $\begin{array}{l}\text { 3xTg-AD } \\
\text { mice }\end{array}$ & Male & $\begin{array}{l}6 \text { months } \\
\text { old }\end{array}$ & $\begin{array}{l}10 \mathrm{mg} / \mathrm{kg} \\
\text { body weight }\end{array}$ & $\begin{array}{l}\text { A } \beta \mathrm{O}, \text { hyper- } \\
\text { phosphorylated } \\
\text { tau }\end{array}$ & $\begin{array}{l}\text { Decreased number of } \mathrm{A} \beta \\
\text { oligomers and } \\
\text { hyperphosphorylated tau } \\
\text { Protection from cognitive } \\
\text { impairment, brain } \\
\text { oxidative stress, decrease } \\
\text { in mitochondrial DNA }\end{array}$ & $\mathrm{N} / \mathrm{A}$ & [78] \\
\hline $\begin{array}{l}\text { SD rats } \\
\text { treated with } \\
\text { LPS }\end{array}$ & $\mathrm{N} / \mathrm{A}$ & $\mathrm{N} / \mathrm{A}$ & $\begin{array}{l}5 \text { and } 10 \\
\mathrm{mg} / \mathrm{kg}\end{array}$ & $\begin{array}{l}\text { Inflammation, } \\
\text { oxidation, } \\
\text { increased AChE } \\
\text { activity }\end{array}$ & $\begin{array}{l}\text { Lowered levels of induced } \\
\text { inflammation and oxidation }\end{array}$ & $\begin{array}{l}\text { Inhibited } \\
\text { increase in } \\
\text { AchE activity }\end{array}$ & [13] \\
\hline APP695 mice & $\mathrm{N} / \mathrm{A}$ & $\begin{array}{l}4 \text { months } \\
\text { old }\end{array}$ & $10 \mathrm{mg} / \mathrm{kg} /$ day & $\begin{array}{c}\text { A } \beta \text { plaques, } \\
\text { decreased ChAT } \\
\text { levels }\end{array}$ & $\begin{array}{l}\text { Long-term treatment } \\
\text { significantly reduced } A \beta \\
\text { plaque levels }\end{array}$ & $\begin{array}{l}\text { Increased } \\
\text { ChAT activity } \\
\text { in frontal } \\
\text { cortex and } \\
\text { hippocampus }\end{array}$ & [81] \\
\hline $\begin{array}{l}\text { Swiss mice } \\
\text { treated with } \\
\mathrm{AlCl}_{3} \text { and } \\
\text { d-galactose }\end{array}$ & Male & $\mathrm{N} / \mathrm{A}$ & $80 \mathrm{mg} / \mathrm{kg} /$ day & $\begin{array}{c}\text { Affected } \\
\text { cognitive } \\
\text { functions, } \\
\text { decreased BDNF, } \\
\text { CREB and AChE } \\
\text { levels }\end{array}$ & $\begin{array}{ll}\text { - } & \text { Increased BDNF and } \\
\text { - } & \text { CREB levels } \\
\text { Improved memory } \\
\text { deficits }\end{array}$ & $\begin{array}{l}\text { Increased } \\
\text { AChE level }\end{array}$ & [82] \\
\hline
\end{tabular}

\section{Role of Melatonin on Neurotransmission}

The effects of melatonin on neurotransmission primarily involve improvements in cholinergic and glutamatergic systems (see Figure 2). As mentioned previously, A $\beta$ plaques can impair the function of glutamatergic neurons and cause excessive influx of calcium, which lead to overstimulation and unnecessary release of AChE, resulting in reduced choline acetyltransferase and ACh levels. 


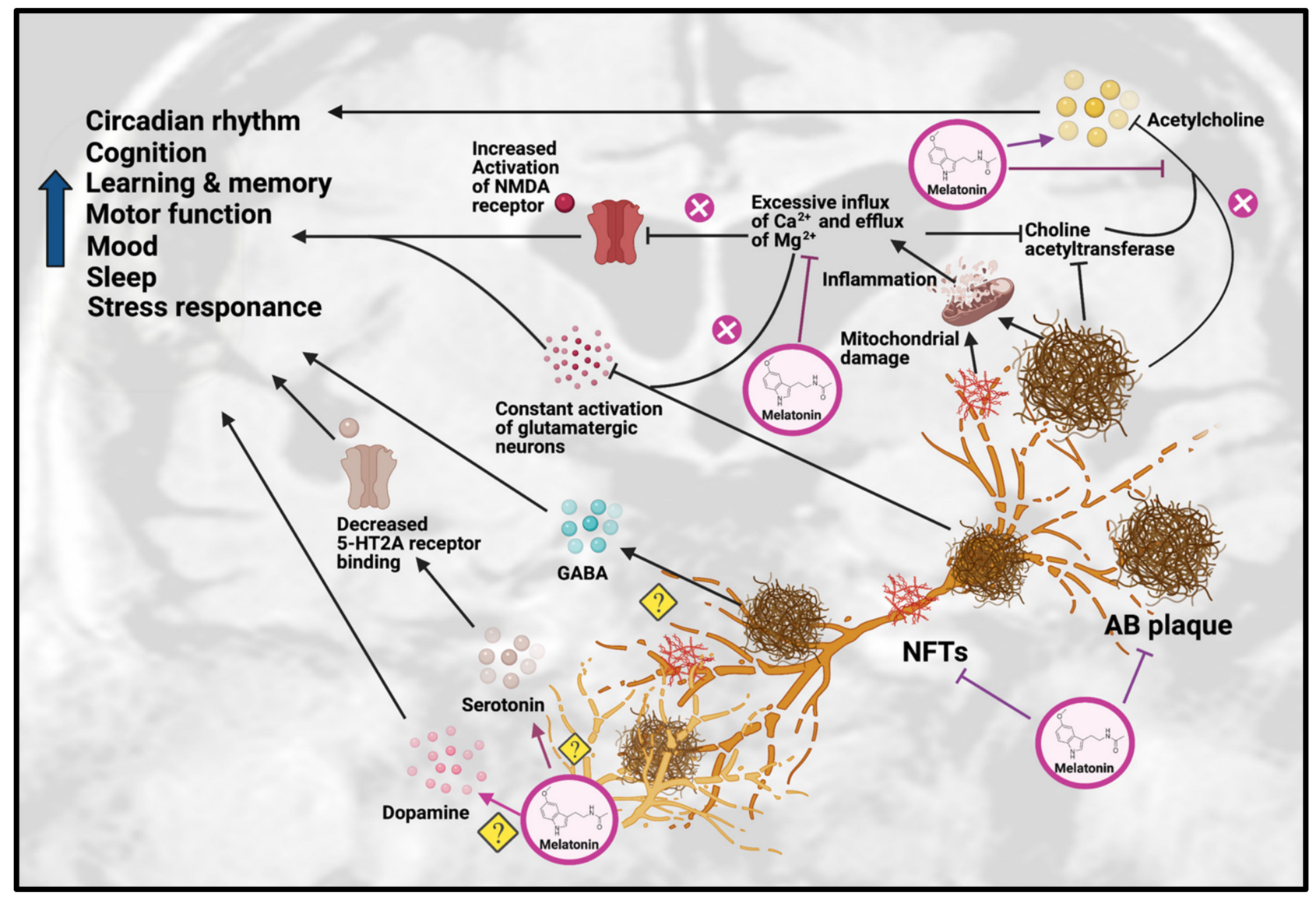

Figure 2. Effects of Melatonin treatment on dysfunction of neurotransmission in AD. Melatonin can ameliorate the formation of $\mathrm{A} \beta$ plaques and NFT, as well as improve the impairments due to these AD hallmarks, including disrupted circadian rhythm, cognition, learning, memory, motor function, mood, sleep and stress response. Melatonin treatment can have beneficial effects on serotonergic and dopaminergic systems, but the exact mechanisms have yet to be determined. Melatonin can also have beneficial effects on the cholinergic system by increasing acetylcholine release and reducing inflammation caused by excessive influx of $\mathrm{Ca}^{2+}$ and excessive efflux of $\mathrm{Mg}^{2+}$, thereby inhibiting choline acetyltransferase. Abbreviations: A $\beta$, Amyloid-beta; NFT, neurofibrillary tangle.

Melatonin has been hypothesized to alleviate the disruption of the cholinergic system in AD through inhibiting the calcium-induced release of AChE, thus effectively acting as an acetylcholine enhancer [3]. Supporting this hypothesis, a study on a sporadic AD rat model showed that melatonin treatment could significantly decrease the level of inflammation and oxidation, as well as inhibit AChE activity [13]. In addition, it has been shown that as $\mathrm{AD}$ progresses, choline acetyltransferase [25] and AChE synthesis begins to decrease, which correlates positively with dementia severity in AD patients. Melatonin has also been shown to promote choline transport, which improved ACh synthesis [69]. In APP695 mice, melatonin treatment significantly decreased ChAT activity in the frontal cortex and hippocampus [81]. In a recent study on sporadic AD mice, melatonin rescued the AChE level and promoted neuroprotection [82].

Melatonin has also been suggested to alleviate the altered glutamatergic system in AD by inhibiting the activity of NMDA receptors. Melatonin was able to reduce excessive $\mathrm{Ca}^{2+}$ influx by altering the activity of voltage-gated $\mathrm{Ca}^{2+}$ channels, thereby inhibiting the effects of NMDA receptors [83]. This was supported by a study on adult male Wistar rats, which found that melatonin treatment attenuated the glutamatergic-dependent excitatory response in striatal neurons by reducing $\mathrm{Ca}^{2+}$ influx in voltage-gated $\mathrm{Ca}^{2+}$ channels and NMDA-gated $\mathrm{Ca}^{2+}$ channels, resulting in an anti-excitotoxic effect [14]. Even though these findings show melatonin has beneficial effects on cholinergic and glutamatergic systems, 
the impact of melatonin on the neurotransmission of monoaminergic systems has yet to be demonstrated, which will require more research.

\section{Conclusions and Future Perspective}

The effects of melatonin on neurotransmission and AD pathologies have been separately investigated in several respective studies. Melatonin is well established as a therapeutic for sleep disorders and jet lag, and has been investigated as an adjunct medication for cancer patients and as a medication for free-radical diseases. In this review, we have explored how melatonin can serve as a therapeutic for AD by inhibiting the pathological progression and restoring cholinergic and glutamatergic neurotransmission. Nevertheless, more research is needed to reveal its effects on other neurotransmitters such as GABA, serotonin, dopamine and histamine. Apart from the study on the direct interaction of melatonin with neurotransmission, the pathway through which melatonin can indirectly clear $A \beta$ plaques is also worth studying since $A \beta$ plaques are the fundamental source to cause neurotransmission dysfunction, and melatonin can reinforce the clearing effect of the glymphatic pathway by utilizing melatonin-AQP4 interaction. In addition, recent preclinical studies have indicated that melatonin metabolite N(1)-Acetyl-N(1)-formyl-5methoxykynuramine, melatonin-derived benzylpyridinium bromides, melatonylvalpromide and melatonin-N,N-Dibenzyl(N-methyl) amine hybrids have neuroprotective effects against AD pathologies [84-87]. Moreover, melatonin receptor agonists piromelatine and agomelatine were found be effective against AD [88,89], but their neuroprotective effects against neurotransmission dysfunction in AD are still unknown. Further preclinical research is needed to investigate the detailed role of these compounds on different neurotransmission systems in AD, and further clinical studies on melatonin and its compounds are needed to validate their efficacy in the different stages of AD. To facilitate future studies, the recent advancement of neurotransmitter imaging techniques including positron emission tomography (PET) and Single-Photon Emission Computed Tomography (SPECT) can be taken into consideration. These are useful for accurate real-time neurotransmission detection. Furthermore, the improvement of the melatonin delivery system and the genetic variation of melatonin response can be evaluated by high-throughput screening and computer-aided drug design [90,91]. Finally, by understanding the mechanisms of how melatonin ameliorates AD pathogenesis, we can further ascertain its therapeutic value. Without a doubt, the future of melatonin as a potential treatment for AD is bright.

Author Contributions: L.W.L. conceived the original idea, developed the outline of the content and rewrote the manuscript. J.R., K.C.T. and J.N. wrote the draft of the manuscript, prepared the figures, and tables in the manuscript. J.R. and K.C.T. revised the manuscript. M.-L.F. and L.W.L. supervised, performed the literature review and improved the manuscript. All authors have read and agreed to the published version of the manuscript.

Funding: This research received no external funding.

Institutional Review Board Statement: Not applicable.

Informed Consent Statement: Not applicable.

Data Availability Statement: Not applicable.

Acknowledgments: This scientific work was supported by the Hong Kong Research Grant Council, and research funding from The University of Hong Kong (Seed Fund for Basic Research and Seed Fund for Translational and Applied Research) awarded to Lee Wei Lim. The figures were created using BioRender.com (Accessed on 27 May 2021).

Conflicts of Interest: All authors declare no conflicts of interest.

\section{References}

1. Lahiri, D.K. Melatonin affects the metabolism of the $\beta$-amyloid precursor protein in different cell types. J. Pineal Res. 1999, 26, 137-146. [CrossRef] [PubMed]

2. Alzheimer's Disease International. World Alzheimer Report 2019; Alzheimer's Disease International: London, UK, $2019 ;$ p. 13. 
3. Mayuri, S.; Piyarat, G.; Parichart, B.; Russel, J.R.; Jutamaad, S. Mechanisms of Melatonin in Alleviating Alzheimer's Disease. Curr. Neuropharmacol. 2017, 15, 1010-1031.

4. Bature, F.; Guinn, B.-A.; Pang, D.; Pappas, Y. Signs and symptoms preceding the diagnosis of Alzheimer's disease: A systematic scoping review of literature from 1937 to 2016. BMJ Open 2017, 7, e015746. [CrossRef] [PubMed]

5. Reddy, P.H. A Critical Assessment of Research on Neurotransmitters in Alzheimer's Disease. J. Alzheimers Dis. 2017, 57, 969-974. [CrossRef] [PubMed]

6. Manczak, M.; Calkins, M.J.; Reddy, P.H. Impaired mitochondrial dynamics and abnormal interaction of amyloid beta with mitochondrial protein Drp1 in neurons from patients with Alzheimer's disease: Implications for neuronal damage. Hum. Mol. Genet. 2011, 20, 2495-2509. [CrossRef] [PubMed]

7. McEnery, M.W.; Siegel, R.E. Neurotransmitter Receptors, 2nd ed.; Elsevier Inc.: Oxford, UK, 2014; pp. 552-564.

8. Araque, A.; Parpura, V.; Sanzgiri, R.P.; Haydon, P.G. Tripartite synapses: Glia, the unacknowledged partner. Trends Neurosci. 1999, 22, 208-215. [CrossRef]

9. Kandimalla, R.; Reddy, P.H. Therapeutics of Neurotransmitters in Alzheimer's Disease. J. Alzheimers Dis. 2017, 57, 1049-1069. [CrossRef] [PubMed]

10. Wong, K.Y.; Roy, J.; Fung, M.L.; Heng, B.C.; Zhang, C.; Lim, L.W. Relationships between mitochondrial dysfunction and neurotransmission failure in Alzheimer's disease. Aging Dis. 2020, 11, 1291. [CrossRef]

11. Šimić, G.; Babić Leko, M.; Wray, S.; Harrington, C.R.; Delalle, I.; Jovanov-Milošević, N.; Bažadona, D.; Buée, L.; de Silva, R.; Di Giovanni, G.; et al. Monoaminergic neuropathology in Alzheimer's disease. Prog. Neurobiol. 2017, 151, 101-138. [CrossRef]

12. Pandiperumal, S.; Trakht, I.; Srinivasan, V.; Spence, D.; Maestroni, G.; Zisapel, N.; Cardinali, D. Physiological effects of melatonin: Role of melatonin receptors and signal transduction pathways. Prog. Neurobiol. 2008, 85, 335-353. [CrossRef]

13. Tyagi, E.; Agrawal, R.; Nath, C.; Shukla, R. Effect of melatonin on neuroinflammation and acetylcholinesterase activity induced by LPS in rat brain. Eur. J. Pharm. 2010, 640, 206-210. [CrossRef]

14. Escames, G.; Macías, M.; León, J.; García, J.; Khaldy, H.; Martín, M.; Vives, F.; Acuña-Castroviejo, D. Calcium-Dependent Effects of Melatonin Inhibition of Glutamatergic Response in Rat Striatum. J. Neuroendocr. 2001, 13, 459-466. [CrossRef]

15. Hardy, J. The Amyloid Hypothesis of Alzheimer's Disease: Progress and Problems on the Road to Therapeutics. Science 2002, 297, 353-356. [CrossRef]

16. Iliff, J.J.; Chen, M.J.; Plog, B.A.; Zeppenfeld, D.M.; Soltero, M.; Yang, L.; Singh, I.; Deane, R.; Nedergaard, M. Impairment of glymphatic pathway function promotes tau pathology after traumatic brain injury. J. Neurosci. 2014, 34, 16180-16193. [CrossRef]

17. Mestre, H.; Hablitz, L.M.; Xavier, A.L.; Feng, W.; Zou, W.; Pu, T.; Monai, H.; Murlidharan, G.; Rivera, R.M.C.; Simon, M.J. Aquaporin-4-dependent glymphatic solute transport in the rodent brain. eLife 2018, 7, e40070. [CrossRef]

18. Kitchen, P.; Salman, M.M.; Halsey, A.M.; Clarke-Bland, C.; MacDonald, J.A.; Ishida, H.; Vogel, H.J.; Almutiri, S.; Logan, A.; Kreida, S. Targeting aquaporin-4 subcellular localization to treat central nervous system edema. Cell 2020, 181, 784-799.e19. [CrossRef]

19. Sylvain, N.J.; Salman, M.M.; Pushie, M.J.; Hou, H.; Meher, V.; Herlo, R.; Peeling, L.; Kelly, M.E. The effects of trifluoperazine on brain edema, aquaporin-4 expression and metabolic markers during the acute phase of stroke using photothrombotic mouse model. Biochim. Biophys. Acta (BBA)-Biomembr. 2021, 1863, 183573. [CrossRef]

20. Herrup, K. Reimagining Alzheimer's Disease-An Age-Based Hypothesis. J. Neurosci. 2010, 30, 16755-16762. [CrossRef]

21. Vlad, S.C.; Miller, D.R.; Kowall, N.W.; Felson, D.T. Protective effects of NSAIDs on the development of Alzheimer disease. Neurology 2008, 70, 1672-1677. [CrossRef]

22. Yang, Y.; Mufson, E.J.; Herrup, K. Neuronal Cell Death Is Preceded by Cell Cycle Events at All Stages of Alzheimer's Disease. J. Neurosci. 2003, 23, 2557-2563. [CrossRef]

23. Talita, H.F.-V.; Isabella, M.G.; Flavia, R.S.; Fabiola, M.R. Alzheimer's disease: Targeting the Cholinergic System. Curr. Neuropharmacol. 2016, 14, 101-115.

24. Perry, E.K.; Perry, R.H.; Blessed, G.; Tomlinson, B.E. Changes in brain cholinesterases in senile dementia of Alzheimer type. Neuropathol. Appl. Neurobiol. 1978, 4, 273-277. [CrossRef] [PubMed]

25. Hampel, H.; Mesulam, M.M.; Cuello, A.C.; Farlow, M.R.; Giacobini, E.; Grossberg, G.T.; Khachaturian, A.S.; Vergallo, A.; Cavedo, E.; Snyder, P.J.; et al. The cholinergic system in the pathophysiology and treatment of Alzheimer's disease. Brain 2018, 141, 1917-1933. [CrossRef] [PubMed]

26. Boncristiano, S.; Calhoun, M.E.; Kelly, P.H.; Pfeifer, M.; Bondolfi, L.; Stalder, M.; Phinney, A.L.; Abramowski, D.; Sturchler-Pierrat, C.; Enz, A. Cholinergic changes in the APP23 transgenic mouse model of cerebral amyloidosis. J. Neurosci. 2002, 22, 3234-3243. [CrossRef]

27. Van Dam, D.; Marescau, B.; Engelborghs, S.; Cremers, T.; Mulder, J.; Staufenbiel, M.; De Deyn, P.P. Analysis of cholinergic markers, biogenic amines, and amino acids in the CNS of two APP overexpression mouse models. Neurochem. Int. 2005, 46, 409-422. [CrossRef]

28. Perez, S.E.; He, B.; Muhammad, N.; Oh, K.-J.; Fahnestock, M.; Ikonomovic, M.D.; Mufson, E.J. Cholinotrophic basal forebrain system alterations in 3xTg-AD transgenic mice. Neurobiol. Dis. 2011, 41, 338-352. [CrossRef]

29. Robertson, R.T.; Baratta, J.; Yu, J.; LaFerla, F.M. Amyloid- $\beta$ expression in retrosplenial cortex of triple transgenic mice: Relationship to cholinergic axonal afferents from medial septum. Neuroscience 2009, 164, 1334-1346. [CrossRef] 
30. Watanabe, T.; Yamagata, N.; Takasaki, K.; Sano, K.; Hayakawa, K.; Katsurabayashi, S.; Egashira, N.; Mishima, K.; Iwasaki, K.; Fujiwara, M. Decreased acetylcholine release is correlated to memory impairment in the Tg2576 transgenic mouse model of Alzheimer's disease. Brain Res. 2008, 1249, 222-228. [CrossRef]

31. Bellucci, A.; Luccarini, I.; Scali, C.; Prosperi, C.; Giovannini, M.G.; Pepeu, G.; Casamenti, F. Cholinergic dysfunction, neuronal damage and axonal loss in TgCRND8 mice. Neurobiol. Dis. 2006, 23, 260-272. [CrossRef]

32. German, D.C.; Yazdani, U.; Speciale, S.G.; Pasbakhsh, P.; Games, D.; Liang, C.L. Cholinergic neuropathology in a mouse model of Alzheimer's disease. J. Comp. Neurol. 2003, 462, 371-381. [CrossRef]

33. Bales, K.R.; Tzavara, E.T.; Wu, S.; Wade, M.R.; Bymaster, F.P.; Paul, S.M.; Nomikos, G.G. Cholinergic dysfunction in a mouse model of Alzheimer disease is reversed by an anti-A $\beta$ antibody. J. Clin. Investig. 2006, 116, 825-832. [CrossRef]

34. Ramos-Rodriguez, J.J.; Pacheco-Herrero, M.; Thyssen, D.; Murillo-Carretero, M.I.; Berrocoso, E.; Spires-Jones, T.L.; Bacskai, B.J.; Garcia-Alloza, M. Rapid $\beta$-Amyloid Deposition and Cognitive Impairment After Cholinergic Denervation in APP/PS1 Mice. J. Neuropathol. Exp. Neurol. 2013, 72, 272-285. [CrossRef]

35. Govindpani, K.; Calvo-Flores Guzmán, B.; Vinnakota, C.; Waldvogel, H.J.; Faull, R.L.; Kwakowsky, A. Towards a Better Understanding of GABAergic Remodeling in Alzheimer's Disease. Int. J. Mol. Sci. 2017, 18, 1813. [CrossRef]

36. Jo, S.; Yarishkin, O.; Hwang, Y.J.; Chun, Y.E.; Park, M.; Woo, D.H.; Bae, J.Y.; Kim, T.; Lee, J.; Chun, H.; et al. GABA from reactive astrocytes impairs memory in mouse models of Alzheimer's disease. Nat. Med. 2014, 20, 886-896. [CrossRef]

37. Tiwari, V.; Patel, A.B. Impaired glutamatergic and GABAergic function at early age in A $\beta$ Pswe-PS1dE9 mice: Implications for Alzheimer's disease. J. Alzheimers Dis. 2012, 28, 765-769. [CrossRef]

38. Salek, R.M.; Xia, J.; Innes, A.; Sweatman, B.C.; Adalbert, R.; Randle, S.; McGowan, E.; Emson, P.C.; Griffin, J.L. A metabolomic study of the CRND8 transgenic mouse model of Alzheimer's disease. Neurochem. Int. 2010, 56, 937-947. [CrossRef]

39. Mandal, P.K.; Kansara, K.; Dabas, A. The GABA-Working Memory Relationship in Alzheimer's Disease. J. Alzheimers Dis. Rep. 2017, 1, 43-45. [CrossRef]

40. Butterfield, D.A.; Pocernich, C.B. The Glutamatergic System and Alzheimer's Disease: Therapeutic Implications. CNS Drugs 2003, 17, 641-652. [CrossRef]

41. Wenk, G.L. Neuropathologic changes in Alzheimer's disease: Potential targets for treatment. J. Clin. Psychiatry 2006, 67 (Suppl. 3 ), 3-7.

42. Zhang, L.; Qin, Z.; Sharmin, F.; Lin, W.; Ricke, K.M.; Zasloff, M.; Stewart, A.F.; Chen, H.-H. Tyrosine phosphatase PTP1B impairs presynaptic NMDA receptor-mediated plasticity in a mouse model of Alzheimer's disease. Neurobiol. Dis. 2021, 156, 105402. [CrossRef]

43. Ferreira, I.L.; Ferreiro, E.; Schmidt, J.; Cardoso, J.M.; Pereira, C.M.; Carvalho, A.L.; Oliveira, C.R.; Rego, A.C. A $\beta$ and NMDAR activation cause mitochondrial dysfunction involving ER calcium release. Neurobiol. Aging 2015, 36, 680-692. [CrossRef] [PubMed]

44. Wang, R.; Reddy, P.H. Role of glutamate and NMDA receptors in Alzheimer's disease. J. Alzheimers Dis. 2017, 57, 1041-1048. [CrossRef] [PubMed]

45. Hardingham, G.E.; Bading, H. Synaptic versus extrasynaptic NMDA receptor signalling: Implications for neurodegenerative disorders. Nat. Rev. Neurosci. 2010, 11, 682-696. [CrossRef] [PubMed]

46. Corlew, R.; Brasier, D.J.; Feldman, D.E.; Philpot, B.D. Presynaptic NMDA receptors: Newly appreciated roles in cortical synaptic function and plasticity. Neuroscientist 2008, 14, 609-625. [CrossRef]

47. Zhang, Y.; Li, P.; Feng, J.; Wu, M. Dysfunction of NMDA receptors in Alzheimer's disease. Neurol. Sci. 2016, 37, 1039-1047. [CrossRef]

48. Fernández-Tomé, P.; Brera, B.; Arévalo, M.A.-A.; de Ceballos, M.A.L. $\beta$-Amyloid25-35 inhibits glutamate uptake in cultured neurons and astrocytes: Modulation of uptake as a survival mechanism. Neurobiol. Dis. 2004, 15, 580-589. [CrossRef]

49. Talantova, M.; Sanz-Blasco, S.; Zhang, X.; Xia, P.; Akhtar, M.W.; Okamoto, S.-I.; Dziewczapolski, G.; Nakamura, T.; Cao, G.; Pratt, A.E. A $\beta$ induces astrocytic glutamate release, extrasynaptic NMDA receptor activation, and synaptic loss. Proc. Natl. Acad. Sci. USA 2013, 110, E2518-E2527. [CrossRef]

50. Snyder, E.M.; Nong, Y.; Almeida, C.G.; Paul, S.; Moran, T.; Choi, E.Y.; Nairn, A.C.; Salter, M.W.; Lombroso, P.J.; Gouras, G.K. Regulation of NMDA receptor trafficking by amyloid- $\beta$. Nat. Neurosci. 2005, 8, 1051-1058. [CrossRef]

51. Hascup, K.N.; Hascup, E.R. Altered neurotransmission prior to cognitive decline in A $\beta$ PP/PS1 mice, a model of Alzheimer's disease. J. Alzheimers Dis. 2015, 44, 771-776. [CrossRef]

52. von Kienlin, M.; Künnecke, B.; Metzger, F.; Steiner, G.; Richards, J.G.; Ozmen, L.; Jacobsen, H.; Loetscher, H. Altered metabolic profile in the frontal cortex of PS2APP transgenic mice, monitored throughout their life span. Neurobiol. Dis. 2005, 18, 32-39. [CrossRef]

53. Richards, G.; Messer, J.; Faull, R.L.; Stadler, H.; Wichmann, J.; Huguenin, P.; Bohrmann, B.; Mutel, V. Altered distribution of mGlu2 receptors in $\beta$-amyloid-affected brain regions of Alzheimer cases and aged PS2APP mice. Brain Res. 2010, 1363, 180-190. [CrossRef]

54. Hanson, J.E.; Pare, J.-F.; Deng, L.; Smith, Y.; Zhou, Q. Altered GluN2B NMDA receptor function and synaptic plasticity during early pathology in the PS2APP mouse model of Alzheimer's disease. Neurobiol. Dis. 2015, 74, 254-262. [CrossRef]

55. Steele, J.W.; Brautigam, H.; Short, J.A.; Sowa, A.; Shi, M.; Yadav, A.; Weaver, C.M.; Westaway, D.; Fraser, P.E.; St George-Hyslop, P.H. Early fear memory defects are associated with altered synaptic plasticity and molecular architecture in the TgCRND8 Alzheimer's disease mouse model. J. Comp. Neurol. 2014, 522, 2319-2335. [CrossRef] 
56. Borroni, B.; Costanzi, C.; Padovani, A. Genetic susceptibility to behavioural and psychological symptoms in Alzheimer disease. Curr. Alzheimer Res 2010, 7, 158-164. [CrossRef]

57. Liu, Y.; Yoo, M.-J.; Savonenko, A.; Stirling, W.; Price, D.L.; Borchelt, D.R.; Mamounas, L.; Lyons, W.E.; Blue, M.E.; Lee, M.K. Amyloid Pathology Is Associated with Progressive Monoaminergic Neurodegeneration in a Transgenic Mouse Model of Alzheimer's Disease. J. Neurosci. 2008, 28, 13805-13814. [CrossRef]

58. Ledo, J.H.; Azevedo, E.P.; Beckman, D.; Ribeiro, F.C.; Santos, L.E.; Razolli, D.S.; Kincheski, G.C.; Melo, H.M.; Bellio, M.; Teixeira, A.L.; et al. Cross Talk Between Brain Innate Immunity and Serotonin Signaling Underlies Depressive-Like Behavior Induced by Alzheimer's Amyloid- Oligomers in Mice. J. Neurosci. 2016, 36, 12106-12116. [CrossRef]

59. Holm, P.; Ettrup, A.; Klein, A.B.; Santini, M.A.; El-Sayed, M.; Elvang, A.B.; Stensbøl, T.B.; Mikkelsen, J.D.; Knudsen, G.M.; Aznar, S. Plaque Deposition Dependent Decrease in 5-HT2A Serotonin Receptor in A $\beta$ PPswe/PS1dE9 Amyloid Overexpressing Mice. J. Alzheimers Dis. 2010, 20, 1201-1213. [CrossRef]

60. Palmer, A.M.; Wilcock, G.K.; Esiri, M.M.; Francis, P.T.; Bowen, D.M. Monoaminergic innervation of the frontal and temporal lobes in Alzheimer's disease. Brain Res. 1987, 401, 231-238. [CrossRef]

61. Roh, J.H.; Huang, Y.; Bero, A.W.; Kasten, T.; Stewart, F.R.; Bateman, R.J.; Holtzman, D.M. Disruption of the sleep-wake cycle and diurnal fluctuation of $\beta$-amyloid in mice with Alzheimer's disease pathology. Sci. Transl. Med. 2012, 4, 150ra122. [CrossRef]

62. Dahlstroem, A.; Fuxe, K. Evidence for the existence of monoamine-containing neurons in the central nervous system. I. Demonstration of monoamines in the cell bodies of brain stem neurons. Acta Physiol. Scand. Suppl. 1964, 232, 1-55.

63. Storga, D.; Vrecko, K.; Birkmayer, J.G.D.; Reibnegger, G. Monoaminergic neurotransmitters, their precursors and metabolites in brains of Alzheimer patients. Neurosci. Lett. 1996, 203, 29-32. [CrossRef]

64. Ambrée, O.; Richter, H.; Sachser, N.; Lewejohann, L.; Dere, E.; de Souza Silva, M.A.; Herring, A.; Keyvani, K.; Paulus, W.; Schäbitz, W.-R. Levodopa ameliorates learning and memory deficits in a murine model of Alzheimer's disease. Neurobiol. Aging 2009, 30, 1192-1204. [CrossRef]

65. Vorobyov, V.; Bakharev, B.; Medvinskaya, N.; Nesterova, I.; Samokhin, A.; Deev, A.; Tatarnikova, O.; Ustyugov, A.A.; Sengpiel, F.; Bobkova, N. Loss of Midbrain Dopamine Neurons and Altered Apomorphine EEG Effects in the 5xFAD Mouse Model of Alzheimer's Disease. J. Alzheimers Dis. 2019, 70, 241-256. [CrossRef]

66. Cordella, A.; Krashia, P.; Nobili, A.; Pignataro, A.; La Barbera, L.; Viscomi, M.T.; Valzania, A.; Keller, F.; Ammassari-Teule, M.; Mercuri, N.B.; et al. Dopamine loss alters the hippocampus-nucleus accumbens synaptic transmission in the Tg2576 mouse model of Alzheimer's disease. Neurobiol. Dis. 2018, 116, 142-154. [CrossRef]

67. Mihardja, M.; Roy, J.; Wong, K.Y.; Aquili, L.; Heng, B.C.; Chan, Y.S.; Fung, M.L.; Lim, L.W. Therapeutic potential of neurogenesis and melatonin regulation in Alzheimer's disease. Ann. N. Y. Acad. Sci. 2020, 1478, 43-62. [CrossRef]

68. Pappolla, M.; Bozner, P.; Soto, C.; Shao, H.; Robakis, N.K.; Zagorski, M.; Frangione, B.; Ghiso, J. Inhibition of Alzheimer $\beta$-Fibrillogenesis by Melatonin. J. Biol. Chem. 1998, 273, 7185-7188. [CrossRef]

69. Rosales-Corral, S.A.; Acuña-Castroviejo, D.; Coto-Montes, A.; Boga, J.A.; Manchester, L.C.; Fuentes-Broto, L.; Korkmaz, A.; Ma, S.; Tan, D.-X.; Reiter, R.J. Alzheimer's disease: Pathological mechanisms and the beneficial role of melatonin. J. Pineal Res. 2012, 52, 167-202. [CrossRef]

70. O'Neal-Moffitt, G.; Delic, V.; Bradshaw, P.C.; Olcese, J. Prophylactic melatonin significantly reduces Alzheimer's neuropathology and associated cognitive deficits independent of antioxidant pathways in A $\beta$ PPswe/PS1 mice. Mol. Neurodegener. 2015, 10. [CrossRef]

71. Olcese, J.M.; Cao, C.; Mori, T.; Mamcarz, M.B.; Maxwell, A.; Runfeldt, M.J.; Wang, L.; Zhang, C.; Lin, X.; Zhang, G.; et al. Protection against cognitive deficits and markers of neurodegeneration by long-term oral administration of melatonin in a transgenic model of Alzheimer disease. J. Pineal Res. 2009, 47, 82-96. [CrossRef]

72. Matsubara, E.; Bryant-Thomas, T.; Pacheco Quinto, J.; Henry, T.L.; Poeggeler, B.; Herbert, D.; Cruz-Sanchez, F.; Chyan, Y.-J.; Smith, M.A.; Perry, G.; et al. Melatonin increases survival and inhibits oxidative and amyloid pathology in a transgenic model of Alzheimer's disease. J. Neurochem. 2003, 85, 1101-1108. [CrossRef]

73. Quinn, J.; Kulhanek, D.; Nowlin, J.; Jones, R.; Praticò, D.; Rokach, J.; Stackman, R. Chronic melatonin therapy fails to alter amyloid burden or oxidative damage in old Tg2576 mice: Implications for clinical trials. Brain Res. 2005, 1037, 209-213. [CrossRef]

74. Cardinali, D.P. Melatonin: Clinical perspectives in neurodegeneration. Front. Endocrinol. 2019, 10, 480. [CrossRef]

75. Pappolla, M.; Matsubara, E.; Vidal, R.; Pacheco-Quinto, J.; Poeggeler, B.; Zagorski, M.; Sambamurti, K. Melatonin treatment enhances A $\beta$ lymphatic clearance in a transgenic mouse model of amyloidosis. Curr. Alzheimer Res. 2018, 15, 637-642. [CrossRef] [PubMed]

76. Li, X.-C.; Wang, Z.-F.; Zhang, J.-X.; Wang, Q.; Wang, J.-Z. Effect of melatonin on calyculin A-induced tau hyperphosphorylation. Eur. J. Pharm. 2005, 510, 25-30. [CrossRef] [PubMed]

77. Deng, Y.-Q.; Xu, G.-G.; Duan, P.; Zhang, Q.; Wang, J.-Z. Effects of melatonin on wortmannin-induced tau hyperphosphorylation. Acta Pharm. Sin. 2005, 26, 519-526. [CrossRef] [PubMed]

78. García-Mesa, Y.; Giménez-Llort, L.; López, L.C.; Venegas, C.; Cristòfol, R.; Escames, G.; Acuña-Castroviejo, D.; Sanfeliu, C. Melatonin plus physical exercise are highly neuroprotective in the 3xTg-AD mouse. Neurobiol. Aging 2012, 33, 1124.e11131124.e1129. [CrossRef] [PubMed]

79. Gong, Y.H.; Hua, N.; Zang, X.; Huang, T.; He, L. Melatonin ameliorates A $\beta 1-42$-induced Alzheimer's cognitive deficits in mouse model. J. Pharm. Pharmacol. 2018, 70, 70-80. [CrossRef] [PubMed] 
80. Zhu, L.Q.; Wang, S.H.; Ling, Z.Q.; Wang, D.L.; Wang, J.Z. Effect of inhibiting melatonin biosynthesis on spatial memory retention and tau phosphorylation in rat. J. Pineal Res. 2004, 37, 71-77. [CrossRef]

81. Feng, Z.; Chang, Y.; Cheng, Y.; Zhang, B.-L.; Qu, Z.-W.; Qin, C.; Zhang, J.-T. Melatonin alleviates behavioral deficits associated with apoptosis and cholinergic system dysfunction in the APP 695 transgenic mouse model of Alzheimer's disease. J. Pineal Res. 2004, 37, 129-136. [CrossRef]

82. Labban, S.; Alghamdi, B.S.; Alshehri, F.S.; Kurdi, M. Effects of melatonin and resveratrol on recognition memory and passive avoidance performance in a mouse model of Alzheimer's disease. Behav. Brain Res. 2021, 402, 113100. [CrossRef]

83. Shi, Y.; Fang, Y.-Y.; Wei, Y.-P.; Jiang, Q.; Zeng, P.; Tang, N.; Lu, Y.; Tian, Q. Melatonin in Synaptic Impairments of Alzheimer's Disease. J. Alzheimers Dis. 2018, 63, 911-926. [CrossRef]

84. Rong, K.; Zheng, H.; Yang, R.; Liu, X.; Li, L.; Chen, N.; Zhao, G.; Gong, C.; Deng, Y. Melatonin and its metabolite N (1)-acetyl-N (1)-formyl-5-methoxykynuramine improve learning and memory impairment related to Alzheimer's disease in rats. J. Biochem. Mol. Toxicol. 2020, 34, e22430. [CrossRef]

85. Luo, X.-T.; Wang, C.-M.; Liu, Y.; Huang, Z.-G. New multifunctional melatonin-derived benzylpyridinium bromides with potent cholinergic, antioxidant, and neuroprotective properties as innovative drugs for Alzheimer's disease. Eur. J. Med. Chem. 2015, 103, 302-311. [CrossRef]

86. Wang, X.-C.; Zhang, Y.-C.; Chatterjie, N.; Grundke-Iqbal, I.; Iqbal, K.; Wang, J.-Z. Effect of melatonin and melatonylvalpromide on $\beta$-amyloid and neurofilaments in N2a cells. Neurochem. Res. 2008, 33, 1138-1144. [CrossRef]

87. Buendia, I.; Egea, J.; Parada, E.; Navarro, E.; León, R.; Rodríguez-Franco, M.I.; López, M.G. The Melatonin-N, N-Dibenzyl (N-methyl) amine Hybrid ITH91/IQM157 Affords Neuroprotection in an in Vitro Alzheimer's Model via Hemo-oxygenase-1 Induction. ACS Chem. Neurosci. 2015, 6, 288-296. [CrossRef]

88. He, P.; Ouyang, X.; Zhou, S.; Yin, W.; Tang, C.; Laudon, M.; Tian, S. A novel melatonin agonist Neu-P11 facilitates memory performance and improves cognitive impairment in a rat model of Alzheimer'disease. Horm. Behav. 2013, 64, 1-7. [CrossRef]

89. Yao, K.; Zhao, Y.-F.; Zu, H.-B. Melatonin receptor stimulation by agomelatine prevents A $\beta$-induced tau phosphorylation and oxidative damage in PC12 cells. Drug Des. Dev. Ther. 2019, 13, 387. [CrossRef]

90. Aldewachi, H.; Al-Zidan, R.N.; Conner, M.T.; Salman, M.M. High-Throughput Screening Platforms in the Discovery of Novel Drugs for Neurodegenerative Diseases. Bioengineering 2021, 8, 30. [CrossRef]

91. Salman, M.M.; Al-Obaidi, Z.; Kitchen, P.; Loreto, A.; Bill, R.M.; Wade-Martins, R. Advances in Applying Computer-Aided Drug Design for Neurodegenerative Diseases. Int. J. Mol. Sci. 2021, 22, 4688. [CrossRef] 